Article

\title{
The Confessions of Montaigne
}

\author{
John Jeffries Martin
}

Department of History, Duke University, Durham, NC 27708, USA; E-Mail: john.j.martin@duke.edu

Received: 24 September 2012; in revised form: 10 October 2012 / Accepted: 11 October 2012 /

Published: 15 October 2012

\begin{abstract}
Montaigne rarely repented and he viewed confession-both juridical and ecclesiastical-with skepticism. Confession, Montaigne believed, forced a mode of self-representation onto the speaker that was inevitably distorting. Repentance, moreover, made claims about self-transformation that Montaigne found improbable. This article traces these themes in the context of Montaigne's Essays, with particular attention to "On Some Verses of Virgil" and argues that, for Montaigne, a primary concern was finding a means of describing a self that he refused to reduce, as had Augustine and many other writers before and after him, to the homo interior.
\end{abstract}

Keywords: Montaigne; self; confession; prayer; repentance; interiority; sexuality; sincerity

Montaigne occupies a salient, even a privileged place in the history of the self. His Essays - begun in 1571 and revised almost continuously down to the time of his death in 1592 - constituted, after Augustine's Confessions, the single most important work of introspection prior to Descartes and Rousseau. ${ }^{1}$ Yet, as a form of self-representation, Montaigne's work is particularly complex. The Essays, after all, lack not only the philosophical rigor found in, say, Descartes or Locke; they also lack the narrative form familiar to us in the works of Augustine and Rousseau. Montaigne insists that he can only make sense of himself through "essais," efforts at developing a portrait of who he is under his different aspects, in various associations, in fluctuating moods. Thus, Montaigne does not organize his Essays, despite their autobiographical patina, around a central event. He rejects a narrative and places in its stead what might almost appear to be a series of discontinuous fragments, moving us not seamlessly but with some puzzlement from topic to topic: from (to give what appears to be an especially random ordering) "Sumptuary Laws" to "Sleep" to "The Battle of Dreux" to "Names" to

1 On this genealogy, see inter alia, [1-4]. Citations to the Essays are given first to the French text edited by [5] and then to Frame's translation [6]. 
"The Uncertainty of our Judgment" to "War Horses." And so it is with his life as well. There is no (or little) chronology here, only different experiences captured in relation to various subjects that enabled Montaigne to explore both the world and himself. The Essays, in short, are self-consciously fragmented - a "bundle of so many disparate pieces," as Montaigne describes them ([5], p. 758; [6], p. 574). ${ }^{2}$

But what are we to make of this strange, at times meandering self-representation? Oddly, despite the strangeness of the form of the Essays, scholars have tended to read his work as a kind of bridge from the medieval to the modern self, finding in Montaigne adumbrations of the bourgeois individual. If Augustine desired to make himself known to God, then Montaigne struggled to make himself known to man. The eminent literary historian Erich Auerbach, for instance, famously characterized the Essays as "the first work of lay introspection" ([1], p. 308). And, if Descartes, who read Montaigne with great care, would seek to find a defining internal feature of what made him who he was and he located this in the res cogitans - the thing within each of us that doubts and thinks - Montaigne appears to gesture towards this sense of interiority with his notion of "une forme maistresse." "There is no one," Montaigne writes in his essay "Of Repentance," "who, if he listens to himself, does not discover in himself a pattern all his own, a ruling pattern, which struggles against education and against the tempest of the passions that oppose it" ([5], p. 811; [6], p. 615). Much in Montaigne, therefore, seemingly points towards his role in the shaping of modern identities. As the philosopher Charles Taylor has written, "Montaigne served as a paradigm figure to illustrate another way in which Augustinian inwardness has entered modern life, and he helped to constitute our understanding of the self” ([3], p. 184).

In this essay I examine Montaigne's notion of the self not in relation to the forms of identity that developed over the following centuries but rather in relation to his own time by attending in particular to his deeply ambivalent attitude towards confession. For Montaigne's view of confession stood in stark contrast to the predominant views of both Catholics and Protestants in the sixteenth century. In general Montaigne's contemporaries viewed confession-along with the attendant practice of repentance - as capable of effecting a transformation or an amelioration of self. Yet throughout the Essays Montaigne pushes back against this view. He veers away from confessing in a religious sense; he refuses to repent; above all he does not believe he can change himself in some fundamental sense, even as he self-consciously develops a different way of telling the truth about himself. As a result, the way Montaigne talks about himself offers an ethics of identity that challenged the repressive mechanisms of both Church and State in early modern Europe. Indeed, as the literary scholars Virginia Krause and Reinier Leushuis have recently argued, Montaigne's ambivalence towards confession constituted a self-conscious rejection of the external pressures men and women faced from the late Middle Ages on to reveal themselves to the authorities-both secular and religious - through confessing. For Montaigne, so these authors argue, self-revelation should not be forced, but voluntary; and they relate Montaigne's mode of self disclosure to parrhesia, the Greco-Roman practice of speaking freely about oneself that Foucault examined with great insight in his History of Sexuality [7-9]. There is much about Krause's and Leushuis's framing that I find compelling, especially given that Montaigne was explicit in how horrified he was by the ways in which confession was a practice of

\footnotetext{
2 "Of the resemblance of children to fathers".
} 
violence, not only in the torture chamber ([5], pp. 366-369; [6], pp. 264-266) ${ }^{3}$ but also in the Wars of Religion that ravaged France at his time. At the same time, I wish to suggest that Montaigne's ambivalence towards confession stemmed also from his anthropology: his fundamental belief that we are not easily reformed or transformed and, in this sense too, he broke with the Christian idealism of both Protestants and Catholics who continued to insist that faith and grace-in various configurations - could indeed lead to a transformation of the inner self or a fundamental change in character. Nonetheless, Krause and Leushuis are correct to insist that, for Montaigne, the self was not merely subject to authority. It was not, that is, something to be disclosed purely in the courtroom or the confessional-locations in which it was bound to be distorted. To the contrary, Montaigne's ability to know himself and to describe himself was an exercise in a form of sincerity that did not seek to conform to power but rather to challenge it. His basic understanding of his identity and his approach to self-revelation were closely connected, in my view, to his compassion and his cosmopolitanism as well as to his hatred of torture, of witch-trials, and of the violence unleashed by both Catholics and Calvinists over the matter of confession.

To be sure, there are frequent moments in the Essays in which Montaigne appears to confess, albeit in a decidedly secular or lay fashion. After all, at times, Montaigne seems to want to tell everything, even at the risk of making his readers uncomfortable. Famously, Montaigne's book is a text (often a polemical text) against masking, against dissimulation, against hypocrisy. And it is fitting that Montaigne opens his book with a claim to sincerity: "C'est ici un livre de bonne foy," he writes in his brief address to the reader, adding "I want to be seen here in my simple, natural, ordinary fashion, without straining or artifice, for it is myself that I portray" ([5], p. 3; [6], p. 2). Montaigne returns frequently to the claim that he has nothing to hide. "I have an open way...I do not refrain from saying anything, however grave or burning" ([5], p. 792; [6], p. 600). "A generous heart should not belie its thoughts; it wants to reveal itself even to its inmost depths (jusques au dedans)" ([5], p. 647; [6], p. 491). "I like to see people speak up bravely among gallant men, and to see the words go where the thought goes" ([5], p. 924; [6], p. 705). ${ }^{6}$ And these gestures are confirmed, it seems, by Montaigne's anti-rhetorical essay “On the Vanity of Words” ([5], p. 305-307; [6], pp. 221-223).

At first, therefore, Montaigne's language seems to reflect what we might even describe as an increasing emphasis placed on expression, on openness, on sincerity [10] —ideals that constituted a powerful countercurrent in a culture that was largely characterized by dissimulation [11,12]. In a fundamental sense this current had been fed by the religious ideals of the Reformation and Counter-Reformation. Certainly, the idea that one should either express or be able to express openly what one believed or felt in one's heart had become central to both Protestant and Catholic thinkers in this era. "Our talk must be sincere," Calvin wrote, "that it may be the very image of an upright mind" ([13], Psalm 12:3). And, from the late Middle Ages on, the Catholic doctrine of confession had made self-disclosure an essential component of the sacrament of penance and of one's reconciliation with the Church. Moreover, by the late sixteenth century, this confessional ideal had taken even deeper

\footnotetext{
"Of conscience".

"The useful and the honorable".

"Of presumption".

6 "Of the art of discussion".
} 
roots in Catholic Europe and likely contributed in significant ways to a more generalized notion of the value of self-revelation, not merely to one's priest but also to one's loved-ones, friends, and neighbors. Concern for expression, therefore, was not merely religious; it also spilt over into what was an emerging ideal of sincerity in early modern culture - an ideal that was frequently evoked in this period to critique a political culture that appeared to many to discourage any form of honest speech, especially when addressing one's prince or superiors or even fellow courtiers. Not surprisingly, there are even moments in the Essays in which Montaigne uses the language of confession to describe his desire to make himself known to the world. In the essay "Of Presumption," he even refers to his writing itself as a form of confession ([5], p. 653; [6], p. 495). Yet, while Montaigne rails against hypocrisy and dissimulation, his view of confession is deeply ambivalent; indeed he largely rejects both the act of confession itself and the claim of repentance that often accompanied it as incapable of making sense of his experience.

Confession is a central theme in Montaigne's essay "On Some Verses of Virgil." While most scholars have attended to the erotic surfaces of this essay, which provides a disarmingly frank account of his amours, Montaigne attempted here not only to reflect on his love affairs but also to probe the limits of confession itself. He had already signaled a certain skepticism towards the notion that prayers could be pure or that repentance could be transformative. "I rarely repent," Montaigne had declared in his essay "Of Repentance" ([5], p. 806; [6], p. 612). But that "On Some Verses of Virgil" also constitutes an important discussion of confession becomes clear when, early in the essay, he uses the word "confession" or "confess" six times in as many paragraphs ([5], p. 845-846; [6], pp. 642-643).

What Montaigne means by confession in this essay is by no means obvious. Certainly, his confession is deeply layered. It is a confession simultaneously of his youthful pursuits of the pleasures of the body (forgiven already by Montaigne to himself because they were, he claims, pleasures sought under conditions of honesty) and of his now mature, even aging pursuits of the memory of pleasure. $\mathrm{He}$ is clearly not confessing to reform his youth. He is explicit about this. His recollection of his plaisirs is an important solace. He not only does not condemn his thoughts; he savors them. They rescue him from his melancholia. They are part of who he is - who we all are, even if we deny that this is the case. He had been particularly clear about the fact that confession is not transformative in his essay "On Repentance," where, with considerable irony, he condemns those older men who now claim to be pure: "I hate that accidental repentance that age brings. The man who said ... that he was obliged to the years for having rid him of sensuality had a different viewpoint from mine." "I shall never," Montaigne adds, "be grateful to impotence for any good it may do me...Youth and pleasure in other days did not make me fail to recognize the face of vice in voluptuousness; nor does the distaste that the years bring make me fail to recognize the face of voluptuousness in vice. Now that I am no longer in that state, I judge it as though I were in it" ([5], p. 815; [6], p. 619).

Furthermore, Montaigne's views of confession are reflected also in his attitude toward prayer. As he tells us at the start of his essay "Of prayers," he says no prayer more often than "The Lord's Prayer" ([5], p. 318; [6], p. 230). And yet, in his discussion of prayer as in his discussion of repentance, he recognizes that the mere utterance of pious words is no guarantee of the amendment of self. Too often he notes, "we pray out of habit and custom...all in all, it is only an act" ([5], p. 319; [6], pp. 230-231). And he is distressed that, in the wake of the Reformation, the sacred words of prayer have become almost too familiar and are used too coarsely, without a sense of the need for the proper 
internal state of the supplicant. "It seems, in truth," Montaigne writes at the conclusion of the essay, "that we use our prayers as a jargon, and like those who use holy and divine words for sorceries and magical effects, and that we count on their effect depending on the texture, sound, or sequence of the words, or on our bearing." The failure here, as in his discussion of repentance, is precisely the same: our failure to repent. "For with our souls full of lust, untouched by repentance or by any fresh reconciliation with God, we go and offer him these words that memory lends to our tongue, and hope from them to derive expiation for our sins" ([5], p. 325; [6], p. 236). Perhaps Montaigne, a Roman Catholic, had Calvin in mind. In the Genevan Confession, Calvin had written that "prayer is nothing but hypocrisy and fantasy unless it proceed from the interior affection of the heart" ([14], p. 29).

Confession, therefore, is neither a pious nor religious act for Montaigne. Rather it becomes a kind of brutal honesty about his own identity. Montaigne has "ordered himself" to dare say all that he can. "The diseases of the soul," he writes, "grow more obscure and stronger... That is why they must be handled often in the light of day, with a pitiless hand, be opened up and torn from the hollow of our breast" ([5], p. 846; [6], p. 642). Yet the matter is not only one of self-disclosure, it is also a matter of frank talk about sex, which is usually disavowed, hidden, disguised. Montaigne is perturbed by the hypocrisy of those who "send their conscience to the brothel but keep their countenance in good order" ([5], p. 846; [6], p. 643). And he declares in an exquisitely ironic passage that he will take a different path:

In honor of the Huguenots, who condemn our private and auricular confession, I confess myself in public, religiously and purely. Saint Augustine, Origen, and Hippocrates have published the errors of their opinions; I, besides, those of my conduct. I am hungry to make myself known, and I care not to how many, provided it be truly. Or to put it better, I am hungry for nothing, but I have a mortal fear of being taken to be other than I am by those who come to know my name. ([5], pp. 846-847; [6], p. 643) ${ }^{7}$

Sexuality is a particularly rich field in which to explore the limits of confession as transformative; and "On Some Verses of Virgil" derive their importance, in part, from the way they illuminate Montaigne's notion of the self and what can be said about the self. Love-making, as Virgil describes it in his account of Venus and Vulcan, is especially arresting to Montaigne because it points to an important aspect of how we are in the world. We are overcome by desire and we are brought into peace in the embrace of another. The passage that occasioned the essay was from Book VIII of the Aeneid:

Dixerat; et niveis, hinc atque hinc Diva lacertis

Cunctantem amplexu molli fovet ille repente accepit solitam flammam, notusque medullas intravit calor, et labefacta per ossa cucurrit non secus atque olim, tonitru cum rupta corusco ignea rima micans percurrit lumine nimbus Ea verba loquutus

Optatos dedit amplexus, placidumque petivit

Conjugis infusus gremio per membra soporem.

7 “On some verses of Virgil”. 
[The goddess ceased to speak, and snowy arms outflung

Around him faltering, soft fondling as she clung.

He quickly caught the wonted flame; the heat well-known

Entered his marrow, ran through every trembling bone.

Often a brilliant lightning flash, not otherwise,

Split by a thunderclap, runs through the cloudy skies.

Gave the embraces that she craved; then on her breast

Outpoured at last, gave himself up to sleep and rest.] ([5], p. 849; [6], p. 645)

But, as Montaigne also notes, Virgil's verses were also Lucretius's. In the opening pages of the De rerum natura, Lucretius had called upon Venus to bring Mars into a state of peace, lines that Montaigne introduces by stating "What Virgil says of Venus and Vulcan, Lucretius had better expressed of a stolen enjoyment between her and Mars."

Belli fera moenera Mavors

Armipotens regit, in gremium qui saepe tuum se

Rejicit, aeterno devinctus vulnere amoris...

Pascit amore avidos inhians in te Dea visus,

Eque tuo pendet resupini spiritus ore:

Hunc tu Diva tuo recubantem corpore sancto

Circumfusa super, suaveis ex ore loquelas

Funde

[He who rules the savage things

Of war, the mighty Mars, oft to thy bosom flings

Himself; the eternal wound of love drains all his powers;

Wide-mouthed, with greedy eyes thy person he devours,

Head back, his very soul upon thy lips suspended:

Take him in thy embrace, goddess, let him be blended

With they holy body as he lies; let sweet words pour

Out of they mouth.] ([5], p. 872; [6], p. 664)

Montaigne, who had known Virgil almost his entire life, had first appreciated Lucretius in Dénis Lambin's 1563 edition of the poem (On Montaigne's readings of Lucretius, see [15]). In reading the poem, he recognized at once-so we learn from his own annotations-Virgil's reliance in his description of love-making on Lucretius. Montaigne finds Lucretius's language especially captivating. He praises it for its vividness, its naturalness. In part, his praise of the poem is part of a larger anti-rhetorical emphasis we find throughout the Essays. But it is also clear that Montaigne finds in Lucretius something he admires even more. Lucretius's words are not "of air, but of flesh and bone," Montaigne writes, adding "elles signifient plus qu'elle ne dissent" ([5], p. 873; [6], p. 665). What Montaigne values, that is, is a language that is powerful, natural, and descriptive of the thing itself-he is not interested, he claims, in the false truths of the rhetoricians. 
For many, of course, the discourse of sexuality in Europe at this time was the discourse of the confessional - at least in theory. And, in this sense, Montaigne's "On Some Verses of Virgil" might be read as a kind of counter-confession. He repudiates the idea that sex is in any way shameful. "What has the sexual act, so natural, so necessary, and so just, done to mankind, for us not to talk about it without shame and for us to exclude it from serious and decent conversation?" ([5], p. 847; [6], p. 644). This is an important move. Montaigne's language about sexuality celebrates its naturalness. He will talk frankly about it, because it is a fundamental part of who he is, who we all are. And it is not an act that is confined to marriage. "Marriage," he writes, "has for its share utility, justice, honor, and constancy; a flat pleasure, but more universal. Love is founded on pleasure alone, and in truth its pleasure is more stimulating, lively, and keen, a pleasure inflamed by difficulty" ([5], p. 854; [6], p. 649). But, despite these differences, there is in both cases, as Montaigne describes it, something profoundly natural about the body (not the soul) reaching out to another body. Montaigne sees this as a matter of balance, of the way he personally is. And he rejects the notion that the soul is superior to the body.

May we not say that there is nothing in us during this earthly imprisonment that is purely either corporeal or spiritual, and that we do wrong to tear apart a living man, and that it seems somewhat reasonable that we should behave as favorably at least towards the use of pleasure as we do of pain....For it is indeed reasonable, as they say, that the body should not follow its appetites to the disadvantage of the mind, but why is it not also reasonable that the mind should not pursue its appetites to the disadvantage of the body. ([5], p. 893 ; [6], p. 681$)^{8}$

Montaigne had similar misgivings about repentance. To be sure, Montaigne does not reject repentance entirely. For those sins that are out of character, by which "we are carried away by passion," one could repent and credibly promise not to commit them again. And in such cases, Montaigne adds, "vice leaves repentance in the soul, like an ulcer in the flesh" ([5], p. 806; [6], p. 612). " But as for these other sins so many times repeated, planned, and premeditated, constitutional sins, or even professional or vocational sins, I cannot imagine that they can be implanted so long in one and the same heart, without the reason and conscience of their possessor constantly willing and intending it to be so. And the repentance which he claims comes to him at a certain prescribed moment is a little hard for me to imagine and conceive" ([5], p. 812; [6], pp. 616-617).

Repentance was not possible, that is, for those sins that are constitutional. For these sins, Montaigne maintains, the mind and one's desires have already consented. They are practiced over and over again; they are habitual. They are "rooted and anchored in a strong and vigorous will [and] cannot be denied." ([5], p. 808; [6], p. 613) It would be hypocritical to claim that one could repent of them, and be changed or reformed. For in such cases, "repentance is nothing but a disavowal of our will and an opposition to our fancies, which leads us about in all directions" ([5], p. 808; [6], p. 613).

Although Montaigne does not approve of the notion of repentance as a matter of personal reform, he does acknowledge the power of what we might call a social repentance in which a person who has transgressed against another seeks to set things right or make them whole again. In his essay "On repentance," Montaigne shares an especially revealing anecdote. While visiting a relative at Armagnac,

\footnotetext{
"On some verses of Virgil".

9 "Of repentance".
} 
a region just to the southeast of Bordeaux, Montaigne had met a peasant whom he calls simply "le larron," the thief. The peasant's story points to what we might see as a more archaic form of reconciliation, one that possibly predates the Christian emphasis on confession and repentance. ${ }^{10}$ Born into poverty, the peasant found that he had to steal in order to survive. And he spent his life stealing from neighboring fields and estates. But now, Montaigne writes, "he is rich for a man in his station." And then Montaigne adds: "And to make his peace with God for his acquisitions, he says that he spends his days compensating, by good deeds, the successors of the people he robbed....Judging by his description, whether it is true or false, this man regards theft as a dishonorable action and hates it, but hates it less than poverty; he indeed repents of it in itself, but in so far as it was thus counterbalanced and compensated, he does not repent of it" ([5], p. 812; [6], p. 616). ${ }^{11}$

Montaigne is not saying that the thief was without guilt. But Montaigne appears to see the ethic of compensation exemplified by this peasant's story as in many ways superior to the ethics of so many around him, who confess their sins, even as they continue to slaughter one another. What difference do our confessions make, Montaigne seems to be asking, if we are not reformed? And how, he wonders, can our confessions reform us? For Montaigne, confession can be a form of self-disclosure. But it doesn't change us.

In a fundamentals sense, then, Montaigne's Essays, despite their open character, transcend the very practice of confession itself. From Montaigne's standpoint - and I do not think I am exaggerating here - the central problem with confession lay in its insincerity. To confess was to enter too easily into a claim of reform. Either this was a cheapened mode of reform-for example that of the old man repenting of his youthful excesses - or an unnecessary one. And Montaigne's public reflections on sexuality made this especially clear. For in his reflections on this subject, Montaigne was able to capture something of the experience of what it means, in a deep sense, to be human. This is the way I am, Montaigne writes. This is the way we all are. Perhaps if we are honest about our natures, we shall have less need to reform ourselves; and perhaps if we have less need to reform ourselves, we shall have less need to confess; and perhaps if we have less need to confess, we can be more generous and accepting of one another. Confession, in Montaigne's view, was tied not to reform of self but rather to self-knowledge.

This was a powerful lesson during the Wars of Religion in France, the horrifying, seemingly ceaseless conflict that haunts the Essays. And in these wars confession was prominent among the issues over which Catholics and Calvinists were polarized. For Catholics confession remained the gateway to the sacrament of penance. Christians had been enjoined since the early thirteenth century to make an annual confession to their priests. But this was only the first step. They were also expected to approach this sacrament in a state of contrition (genuine sorrow for their sins) and a desire to reform; and then to carry out the penitential acts of satisfaction that the priest imposed. Within this sacrament, repentance was a two-fold process. It involved not only carrying out the penitential acts but, even more important, as the Council of Trent proclaimed not long before the outbreak of the French Wars of Religion, "sorrow of mind a detestation for sin committed with the purpose of not sinning in the future" ([17], Session XIV, Chapter 4). Repentance, in short, assumed that the individual Christians

10 For an interesting perspective on medieval values of reconciliation, see [16].

11 "Of repentance". 
were capable of moral change-what Carlo Borromeo, the Archbishop of Milan, would call "la vera emendatione della vita" [18]. While rejecting both sacerdotal confession and satisfaction, Protestants nonetheless continued to emphasize not only the importance of repentance in the sense of contrition and transformation but also the necessity of confession, though not to a priest but directly to God. Calvin especially would make repentance central to the life of a Christian. To be sure, Calvin saw true repentance as "a special gift of God." Nonetheless, for Calvin and for his followers alike, repentance was understood as "a laying aside of the old, put[ting] on a new mind.... a transformation not only in external works, but in the soul itself" ([19], Book 3, 3.6).

Another way of grasping Montaigne's view of confession is to contrast him with St. Augustine ([20], pp. 214-219). In his essay "On Presumption," Montaigne writes: "For the movements of my soul, I want to confess here what I am aware of" ([5], p. 633; [6], p. 480). To some degree this is an Augustinian gesture, since, for Augustine confession as a form of the recognition of one's shortcomings was the very opposite of presumption, which was a form of vainglorious posturing. Moreover, like Augustine, who had commented in his Enarrationes in Psalmos that "vita mea est confiteri te, domine," ([21], Psalm 30) who held in short that his masterpiece The Confessions could not be disentangled from his life, Montaigne closely identified his book with his person: "I have no more made my book than my book has made me," he tells us in his essay "On Giving the Lie," adding, "a book consubstantial with its author, concerned with my own self, an integral part of my life; not concerned with some third-hand, extraneous purpose, like all other books" ([5], p. 665; [6], p. 504). Both authors, in short, were masters of forms of self-writing in which text and life were interwoven and at moments indistinguishable. Both were engaged in a form of self-examination.

Yet, in other ways, Montaigne departs sharply from Augustine. For the Bishop of Hippo as for many of his contemporaries confession was not only a focus on one's sins, it was also a form of praising God. And this is most decidedly not the case in Montaigne's Essays. To be sure, he uses the word "confess" frequently, but, apart from one particularly complex passage in which he does seem to have an explicitly religious idea in mind, he generally uses it in a legal rather than a theological sense. Confession was, for Montaigne, a form of admission to a crime or to a plan or to a thought more than a form of seeking amendment or improvement.

More decisively, Montaigne also rejects the cultivation of the narrative self for which Augustine's Confessions was the preeminent example, though remarkably this was a text that Montaigne (who cites several other works by Augustine in his Essays) may not have known. ${ }^{12}$ In the Augustinian narrative life takes on meaning around certain key turning points-conversion above all but also moments of contrition - and the individual was seen as a pilgrim on an earthly journey, whether one was aided by a priest, as in the Catholic tradition, or made this journey on one's own, as in the Protestant. Fundamentally the Augustinian self is represented within the framework of a narrative of grace. The Essays, by contrast, do not assume a narrative form; and Montaigne does not share Augustine's view that reform of self was possible. To the contrary, Montaigne believes he can best capture

12 Several scholars (among them [22,23]) have argued that Montaigne did not know the Confessions, but others believe this unlikely. Auerbach's view that Montaigne must "have been aware at least of the existence and character of this famous book" is, in my view, compelling [1]. 
himself through a series of portraits over time, viewing himself in different circumstances and from varying perspectives.

"I study myself more than any other subject. That is my metaphysics, that is my physics" ([5], p. 1072; [6], p. 821). ${ }^{13}$ In the Essays, Montaigne has, in fact, made himself his subject, with the curious result that he is both the observer and the observed. But he does not render this subject stable. To the contrary, the subject he observes is not constant. He compares his mind to a "runaway horse" that "gives birth to so many chimeras and fantastic monsters, one after another, without order or purpose, that in order to contemplate their ineptitude and strangeness at my pleasure, I have begun to put them in writing" ([5], p. 33; [6], p. 21). "Others form man," he writes at the beginning of his essay "Of Repentance," adding, "I tell of him, and portray a particular one, very ill-formed... Now the lines of my painting do not go astray, though they change and vary. The world is but a perennial movement....I cannot keep my subject still. It goes along befuddled and staggering, with a natural drunkenness. I take it in this condition, just as it is at the moment I give my attention to it. I do not portray being; I portray passing...This is a record of various and changeable occurrences, and of irresolute and, when it so befalls, contradictory ideas: whether I am different myself, or whether I take hold of my subjects in different circumstances and aspects" ([5], p. 805; [6], pp. 610-611). ${ }^{15}$ But the self is not only changeable, it is complex to know. "We are all patchwork, and so shapeless and diverse in composition that each bit, each moment, plays its own game. And there is as much difference between us and ourselves as between us and others. Consider it a great thing to play the part of one single man [Seneca]... In view of this, a sound intellect will refuse to judge men simply by their outward actions; we must probe the inside and discover what springs set a man in motion. But since this is an arduous and hazardous undertaking, I wish fewer people would meddle with it" ([5], p. 337; [6], p. 244). ${ }^{16}$

Yet Montaigne's decision to write, to take an inventory of himself in different moments and in different settings, helps him in the end get at something more fixed: "In modeling this figure upon myself," he writes, "I have had to fashion and compose myself so often to bring myself out, that the model (le patron) itself has to some extent grown firm and taken shape. Painting myself for others, I have painted my inward self with colors clearer than my original ones....Have I wasted my time by taking stock of myself so continually, so carefully? For those who go over themselves only in their minds and occasionally in speech do not penetrate to essentials in their examination as does a man who makes that his study, his work, and his trade, who binds himself to keep an enduring account, with all his faith, with all his strength" ([5], p. 665; [6], p. 504). ${ }^{17}$ It is in this dynamic sense-with a deep consciousness of the mutability, even the fluidity of self - that Montaigne claims he is setting forth nature not artifice: "Those of us especially who live a private life that is on display only to ourselves must have a pattern established within us by which to test our actions and, according to this pattern,

13 "Of experience".

14 "Of idleness".

15 Following Brody [24], Strier, argues that this passage does not imply, as many scholars suggest, that Montaigne's view of the self as fluid or postmodern, but Strier's reading of "soit que je sois autre moymesme, soit que je saissie les subjects par autres circonstances et considerations" flattens the subtle interplay of a relatively fluid self embedded in Montaigne's French ([25], p. 218).

16 "Of the inconsistency of our actions".

17 "Of Giving the Lie". 
now pat ourselves on the back, now punish ourselves. I have my own laws and court to judge me, and I address myself to them more than anywhere else" ([5], p. 807; [6], p. 613). ${ }^{18}$

In early modern Europe the ideas of St. Augustine proved enormously influential. Perhaps they resonated with a culture that scholars, ever since Burckhardt, have portrayed as deeply duplicitous - a period in which heretics, merchants, courtiers, and rulers learned to conceal their thoughts and feelings in the dangerous realm of social interactions that lay before them. In this era, as William Bouwsma has argued, "a relaxed and candid self-exposure now became dangerous; human intimacy was inhibited by the need for vigilance in masking the true self" ([26], p. 169). Moreover, like Augustine Renaissance men and women tended to think that the inner self was the more authentic self, and this perspective would enjoy a rich afterlife in the works of such writers as Descartes, Locke, and Rousseau.

Like many of his contemporaries, Montaigne was disturbed by the hypocrisies of his generation, and he warned his readers not to let themselves "be taken in by either the face or the words of one who takes pride in being always different outside and inside" ([5], p. 648; [6], p. 491). ${ }^{19}$ But Montaigne did not believe that confession in the traditional religious sense could close the gap between one's interior and one's public life. If, that is, sincerity was for most of Montaigne's contemporaries the outward expression or avowal of one's internal beliefs and feelings - an ethic modeled on confession-for Montaigne, sincerity was a far more wrenching process: not the expression of one's beliefs or feelings but rather the portrayal of one's very being. This was Montaigne's most radical claim: "I want to be seen here in my simple, natural, ordinary fashion, without straining or artifice; for it is myself I portray" ([5], p. 3; [6], p. 2). ${ }^{20}$ The image of portraiture, as we have seen, is fundamental. Moreover, even when Montaigne discusses his frankness, it is as though he is describing a kind of hydraulic process and not a sense of the need to express himself: "But besides the fact that I am made that way, I have not a supple enough mind to sidestep a sudden question and escape it by some dodge, or to invent a truth, or a good enough memory to retain something thus invented, and certainly not enough assurance to maintain it; and I put on a bold face because of weakness. Therefore I give myself up to being candid and always saying what I think, by inclination and by reason, leaving it to Fortune to guide the outcome" ([5], p. 610; [6], p. 492). ${ }^{21}$

Did Montaigne's self-acknowledged poor memory make Augustine's solution to self-understanding inaccessible to him? For Augustine, it was memory above all that served as the reservoir of identity, even when memory failed ([27], Book 10). Perhaps, in the absence of a good memory, Montaigne had no choice but to portray rather than to express himself. Perhaps he had no choice but to write in order to discover himself. And on the subject of self, Montaigne's writings are strikingly ethnographic [28]. ${ }^{22}$ His gaze upon his self, that is, resembles his gaze upon others, both within his own culture and beyond. He reports and he portrays; he does not express in Augustinian fashion his thoughts or feelings, and he does not confess. Moreover, it seems that Montaigne's view of the relation of his internal to his external self differed from the views of most of his contemporaries. For, well before Montaigne was

\footnotetext{
18 "Of repentance".

19 "Of presumption".

20 "To the reader".

21 "Of presumption".

22 I thank William M. Reddy for this reference.
} 
writing and, indeed, down to our own time, it has been a characteristic of many western thinkers to insist on the priority of what we might call the inner over the exterior self. We tend to believe, that is, that our thoughts and feelings precede our words and that a fundamental characteristic of our individuality lies in our ability to decide what to reveal and what to conceal about our inner lives, our "true" selves. Confession and self-expression more generally become, within this framework, a privileged site for such self-disclosure. In part, as the philosopher Charles Taylor has argued in his important book Sources of the Self, we are able to adopt this interpretation because "we think of our thoughts, ideas, or feelings as being 'within' us, while the objects in the world which these mental states bear on are "without"" ([3], p. 111). But such a view of the self, as Taylor himself emphasizes, is not a universal one, found in all cultures. Rather it is a historical construct. And, indeed within western culture, this localization of the self as inward would, Taylor argues, find its inaugural voice in the writings of St. Augustine for whom the inner self became-no matter what roles we assume in public - the locus not only of moral agency, knowledge, and memory but also of identity ([3], pp. 129-35). But this very construct seems at least partially undone in Montaigne. It seems impossible, in Montaigne's case, to view the true self as the interior self alone. Floating outside Montaigne's inner self is the observant "I" of the author. Montaigne's self is, as Jean Starobinski has observed, a dialectical self, at once "le 'je' observateur et le moi observé" ([29], p. 65). Scholars disagree about the relation between these two aspects of Montaigne's identity. But it is by no means clear that Montaigne would have reduced his true identity to his inner self alone. He was - though this is a matter for further exploration - a man who lived most fully in his associations with others, whether he met them in books or in person. He was a man of broad associations. His identity was deeply social and, as his reflections on his sexuality and on his health make clear, deeply embodied. In the end, the way Montaigne was in the world transcended his inner self which, as a consequence, was only one aspect of his character. Perhaps this too was why Montaigne refused to confess. Confession, in the sixteenth century, was a disciplining strategy, a means of simplifying and sorting identities along religious and political lines. Montaigne is explicit that he cannot so simplify. "I give my soul now one face, now another, according to which direction I turn it." Montaigne writes in his essay "Of the Inconsistency of our Actions," and adds:

If I speak of myself in different ways, that is because I look at myself in different ways. All contradictions may be found in me by some twist and in some fashion. Bashful, insolent; chaste, lascivious; talkative, taciturn; tough, delicate; clever, stupid; surly, affable; lying, truthful; learned, ignorant; liberal, miserly; and prodigal: all this I see in myself to some extent according to how I turn; and whoever studies himself really attentively finds in himself, yes, even in his judgment, this gyration and discord. I have nothing to say about myself absolutely, simply, and solidly, without confusion and without mixture, or in one word. ([5], p. 335; [6], p. 242)

Confession, whether in the courtroom or kneeling before a priest, was not a capacious enough practice to capture such a self. For Montaigne, confession, therefore, was both an inadequate and an overly reductive mode of self-disclosure. Inevitably he feared that he would be misunderstood in such a tribunal, just as he knew so many of his contemporaries were either wrongly convicted or made wrongfully to feel shame about their deeply human lives. 


\section{Acknowledgement}

I am deeply grateful to John Headley, Robin Barnes, Melissa Bullard, David Peterson, and Brett Whalen for their comments on a preliminary version of this paper that I delivered at the Conference "From the Renaissance to the Modern World" at the University of North Carolina, Chapel Hill in November 2011 as well as to the two anonymous readers of this essay. I would also like to thank Caroline Castiglione and Amy Remensnyder at Brown University and Elizabeth Cohen, Tom Cohen, and Natalie Zemon Davis at the University of Toronto for their insights and suggestions on some of my earlier reflections on the Essays. At Duke I am continuously thankful to Valeria Finucci, Sara Galletti, Jehangir Malegam, Tom Robisheaux, Phil Stern, and Giovanni Zanalda for their collegiality and intellectual companionship.

\section{References}

1. Auerbach, Erich. Mimesis: The Representation of Reality in Western Literature. Translated by Willard R. Trask. Princeton, NJ: Princeton Univ. Press, 2003.

2. Porter, Roy, ed. Rewriting the Self: Histories from the Renaissance to the Present. London, UK: Routledge, 1997.

3. Taylor, Charles. Sources of the Self: The Making of Modern Identity. Cambridge, MA: Harvard Univ. Press, 1989.

4. Weintraub, Karl Joachim. The Value of the Individual: Self and Circumstance in Autobiography. Chicago, IL: Univ. of Chicago Press, 1978.

5. de Montaigne, Michel. Les Essais. Edited by Pierre Villey. Paris, FR: Presses universitaires de France, 2004.

6. de Montaigne, Michel. The Complete Essays of Montaigne. Edited and translated by Donald Frame. Stanford, CA: Stanford Univ. Press, 1958.

7. Krause, Virginia. "Confession or Parrhesia: Foucault after Montaigne." In Montaigne after Theory, Theory after Montaigne, edited by Zahi Zalloua. Seattle, WA: Univ. of Washington Press, 2009, 142-160.

8. Leushuis, Reinier. "Montaigne's Parrhesiastes: Foucault's Fearless Speech and Truthtelling in the Essays." In Montaigne after Theory, Theory after Montaigne, edited by Zahi Zalloua. Seattle, WA: Univ. of Washington, 2009, 100-121.

9. Foucault, Michel. Fearless Speech. Edited by Joseph Pearson. Los Angeles, CA: Semiotext(e), 2001.

10. Martin, John Jeffries. Myths of Renaissance Individualism. Houndmills: Palgrave Macmillan, 2004.

11. Snyder, Jon R. Dissimulation and the Culture of Secrecy in Early Modern Europe. Berkeley, CA: Univ. of California Press, 2009.

12. Zagorin, Perez. Ways of Lying: Dissimulation, Persecution, and Conformity in Early Modern Europe. Cambridge, MA: Harvard Univ. Press, 1990.

13. Calvin, John. Commentary on the Book of Psalms. Translated by James Anderson. Edinburgh, UK: Calvin Translation Society, 1845-1849. 
14. Calvin, John. "Genevan Confession.” In Theological Treatises, edited by J. K. S. Reid. London: SCM Press, 1954, 26-33.

15. Passannante, Gerard. The Lucretian Renaissance: Philology and the Afterlife of Tradition. Chicago, IL: Univ. of Chicago Press, 2011.

16. Malegam, Jehangir. "No Peace for the Wicked: Conflicting Visions of Peacemaking in an Eleventh-Century Monastic Narrative." Viator: Medieval and Renaissance Studies (2008): 23-49.

17. The Canons and Decrees of the Council of Trent: Original Text with English Translation. Edited and translated by Henry Joseph Schroeder. St. Louis, MO: Herder Book Co., 1941.

18. Borromeo, Carlo. Avvertenze di. Mons. Illustrissimo Cardinale di S. Prassede, Arcivescovo di Milano, ai Confessori nella Città in Acta ecclesiae mediolanensis. Edited by Achille Ratti (later Pope Pius XI). Milan: Pagnonius, 1890, volume 2, 1870-99.

19. Calvin, John. Institutes of the Christian Religion. Translated by Henry Beveridge. Edinburgh: Calvin Translation Society, 1846, 2 volumes.

20. Friedrich, Hugo. Montaigne. Translated by Dawn Eng. Berkeley, CA: Univ. of California Press, 1991.

21. Augustine. Enarrationes in Psalmos. Patrologia Latina. Edited by J.-P. Migne. Paris, FR: Garnier, 1845, volume 35.

22. Abercrombie, Nigel. St. Augustine and French Classical Thought. Oxford, UK: Oxford Univ. Press, 1938.

23. Mathieu-Castellani, Gisèle. La rhétorique des passions. Paris, FR: Presses universitaires de Frnace, 2000.

24. Brody, Jules. “'Du repentir' (III:2): A Philological Reading.” Yale French Studies (1983): 238-272.

25. Strier, Richard. The Unrepentant Renaissance: From Petrarch to Shakespeare. Chicago, IL: Chicago Univ. Press, 2011.

26. Bouwsma, William J. A Usable Past: Essays in European Cultural History. Berkeley, CA: Univ. of California Press, 1990.

27. Augustine. Confessions. Edited by James J. O’Donnell. Oxford, UK: Oxford Univ. Press, 1992, 3 volumes.

28. Hamlin, William. “On Continuities between Skepticism and Early Ethnography; Or, Montaigne's Providential Diversity.” Sixteenth Century Journal 31 (2000): 361-79.

29. Starobinski, Jean. Montaigne en movement. Paris, FR: Gallimard, 1993.

(C) 2012 by the author; licensee MDPI, Basel, Switzerland. This article is an open access article distributed under the terms and conditions of the Creative Commons Attribution license (http://creativecommons.org/licenses/by/3.0/). 